\title{
An Experimental Approach to Know the Role of Sacred Groves in Protecting Soil and Water in Arid Biogeography Province of India
} \section{Vasant Kunj, New Delhi, India. Studies, Vasant Kunj, New Delhi, India \\ Study Area: Kachchh, India \\ Coordinates: $23.915^{\circ} \mathrm{N} ; 70.367^{\circ} \mathrm{E}$}

Amit Pandey ${ }^{*}$, Ranjana R Chaudhuri ${ }^{2}$

${ }^{1}$ Department of Policy Studies, TERI School of Advanced Studies,

${ }^{2}$ Department of Regional Water Studies, TERI School of Advanced

Key words: Kachchh, Reserve forest, Soil moisture, Soil organic matter

\section{Introduction:}

In the desert ecosystem, there is subliminal biodiversity, the concept of community-based conservation in terms of sacred groves has been studied in detail in the Indian scenario but the literature is meagre for Kachchh, Gujarat which is an arid biogeographic region of India. Sacred groves are the untouched tract of forests that are conserved on the religious, cultural, and traditional background and revered by the local community (Gadgil \& Vartak, 1976). In India, the tale of conservation through sacred groves in the arid province centres around 'Orans' of Rajasthan, the local people firmly follow the traditional practices of conservation and respect the concept of the sacredness of a particular natural landscape in any form i.e. water body, forest, compensatory plantation and even a stone (Pandey, 1999). The existence of SG on arid biogeographic provinces dates to the ancient era as protection of the natural sacred landscape. Sacred groves (SG) provide ecosystem services through their inherent biodiversity, soil and moisture conservation, nutrient cycling, water regulation, and

\section{Abstract}

After the severe earthquake in Bhuj, Kachchh (2001) there has been a major restructuring including industrial development, in the district like cement industries, fertilizers, and fisheries. The forest land has reduced due to anthropogenic pressures and invasive species like Prosopis juliflora leading to pressures on the biodiversity of the area. In this context the sacred groves in Gugaliyana Reserve Forest, Kachchh, have been taken up for detailed study as the reserve forest is endowed with natural springs and wells which are responsible for the precious freshwater ground resources. The study has revealed that agricultural land located close to the sacred groves has the best soil parameters. No manual inputs like fertilizers and manures are added to improve agricultural productivity near the sacred groves. The villages located within $3 \mathrm{~km}$ of the sacred grove have a relatively high amount of soil moisture and organic matter which allows the farmers to grow the medicinal plant "Guggal" (Commiphora wightii) and pulses. Soil parameters such as soil moisture, organic carbon organic matter and $\mathrm{pH}$ show a negative correlation with distance which implies that the farther we move from the sacred groves the soil parameters get decline which further leads to disrupted soil nutrient cycling.

carbon sequestration. These groves play a very important role in terms of conserving biological diversity and providing livelihood security to the local communities of arid India.

Kachchh is the vulnerable desert district of Gujarat which forms the southern part of the Thar Desert in India. The tropical thorn forest with floral species like Guggal, Commiphora wightii is the overall vegetation and representative of the biogeography of the district (Patel et al., 2014). Gugaliyana Reserve Forest is the only natural forest present in the district with the presence of two sacred groves (Oran Mata and Sadhay Pir) as an integration of two different religions and natural and cultural heritages are preserved similarly. The sacred groves (SG) are within $4 \mathrm{~km}$ of each other inside the Gugaliyana reserve forest which has an area of 2229.26 hectares. Based on the comparative analysis of soil parameters of the two sacred groves of Kachchh, the restoration potential of the degraded sacred groves have been highlighted (Pandey \& Mahato, 2019). An extensive review of the existence and significance of sacred

*Corresponding Author: amit.pandey@terisas.ac.in 
groves in the arid deserts of the world has also been reported (Pandey \& Mahato, 2019). It has also been reported that topographic factors affect forests through their direct influence on radiation and moisture as well as influence carbon sequestered in the region. The natural and anthropogenic factors affect the changes in the ecosystem (Maren et al., 2015).

The objective of this study is to find the correlation between soil productivity and distance from the sacred grove using soil parameters like moisture, salinity, and organic matter.

\section{Methodology:}

Study area: the soil samples from the nearby villages and the two sacred groves have been collected, tested, and analyzed for nutrient cycles. Collection of the soil samples was done from in and around the sacred grove. Eight soil samples were collected from the grove premise and another 12 samples were collected from each of the four directions with the distance of $0.5,1.0$, and $1.5 \mathrm{~km}$ away from the sacred grove, making a total of 20 soil samples from both the groves. These soil samples were compared with samples taken from villages up to $15 \mathrm{~km}$ away.

Soil quality analysis: it has been determined based on various physicochemical parameters like $\mathrm{pH}$, Electrical Conductivity, Salinity, and Soil Moisture using the Electrode method and Gravimetric method respectively (Swamy et al., 2003).

Electrode Method:pH, Electrical Conductivity \& Salinity Gravimetric method: Soil moisture Empirical modelling:

$y_{\text {Soil parameters }}=\beta_{\mathrm{o}}+\beta_{1}$ (distance from the sacred groves $)+\beta_{2}$ (area of the farmland) $+\mu(1)$

In equation $1 y_{\text {Soil parameters }}$ is the dependent variable. There are in total six soil parameters (dependent variables) namely soil moisture, organic carbon, organic matter, salinity and electrical conductivity whose description is available in table 1 below. Each of these six dependent variables has been regressed over 2 independent variables namely distance from the sacred groves and area of the farmland. $\mu$ represent a stochastic error in the model.
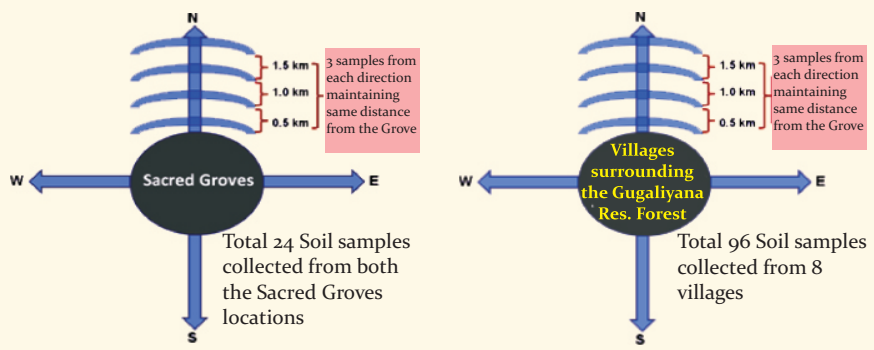

Figure-2: Soil sampling strategies; a) Soil sampling strategy from the two selected sacred groves; b) Soil sampling strategy from the 8 villages around Gugaliyana Reserve Forest
Table 1: Description of variables used in regression analysis

Variable Description

Independent variables

Distance from the sacred groves $(\mathrm{km})$

Distance of farmland from sacred groves( in kilometers)

Land area of the farmland (hectare)

Area of the farmland on which the agrarian activities are taking place

Dependentvariables

Soil moisture

It is the water contained in the soil due to precipitation, temperature etc and affects soil nutrient cycling

Soil Organic matter

It comprises of dead decayed residues of plants and animals which ultimately enhances the fertility of the soil

Soil Organic carbon

It is a measureable component of soil organic matter. Organic matter contributes to nutrient retention and turnover, soil structure, moisture retention and availability, degradation of pollutants, and carbon Soil pH sequestration.

It is a measure of the acidity or basicity of a soil. Soil $\mathrm{pH}$ is a key characteristic that can be used to make informative analysis both qualitative and quantitatively regarding soil characteristics.

Soil Salinity

It is the salt content in the soil; the process of increasing the salt content is known as salinization. Salts occur naturally within soils and water.

Soil Electrical conductivity

It (EC) is a measure of the amount of salts in soil (salinity of soil). It is an important indicator of soil health. Excess salts hinder plant growth by affecting the soil-water balance. Soils containing excess salts occur naturally in arid and semiarid climates.

\section{Results and Discussion:}

The soil analysis has been done at the micro-level (each village) to study the influence of the sacred groves through Physicochemical and organic properties of the soil which are represented in Tables-2, 3

Table-2: Soil pH (pH), Soil Moisture (SM; \%), Electrical Conductivity (EC; micro simens $\mu \mathrm{S})$, Water Soluble Salts (WSS; ppm), Salinity (S; \%)

\begin{tabular}{llllll}
\hline Sample ID & $\mathrm{pH}$ & $\mathrm{SM}$ & $\mathrm{EC}$ & WSS & $\mathrm{S}$ \\
\hline ValkaNana & 4.34 & 1.48 & 159.06 & 83.45 & 1 \\
ValkaMota & 5.6 & 1.00 & 102.53 & 53.55 & 1 \\
Dayapar & 2.67 & 0.80 & 1250.00 & 660.23 & 2 \\
Ghadani & 6.1 & 0.57 & 190.90 & 297.18 & 2 \\
Mata Na Madh & 5.8 & 1.16 & 128.10 & 66.82 & 1 \\
Lifri & 5.9 & 1.87 & 371.63 & 195.4 & 1 \\
Oran Mata & 6.0 & 1.52 & 414.70 & 214.76 & 1 \\
Paneli & 4.9 & 0.54 & 49.49 & 23.72 & 2 \\
Dolatpar & 6.3 & 0.31 & 44.73 & 23.56 & 2 \\
SadhayPir & 5.8 & 2.07 & 434.36 & 228.36 & 1 \\
\hline
\end{tabular}


Table.3. Soil: Total organic carbon (TOC), Organic matter (OM), Organic carbon $(\mathrm{OC})$

\begin{tabular}{llll}
\hline Sample ID & \% OC & \% TC & $\%$ OM \\
\hline Valka Nana & 0.63 & 0.81 & 2.40 \\
ValkaMota & 0.15 & 0.19 & 0.56 \\
Dayapar & 0.18 & 0.23 & 0.68 \\
Ghadani & 0.18 & 0.23 & 0.68 \\
Mata Na Madh & 0.48 & 0.62 & 1.83 \\
Lifri o.06 & 0.07 & 0.20 & \\
Oran Mata & 0.33 & 0.42 & 1.24 \\
Paneli & 0.57 & 0.74 & 2.19 \\
Dolatpar & 0.33 & 0.42 & 1.24 \\
SadhayPir & 0.18 & 0.23 & 0.68 \\
\hline
\end{tabular}

Table 4. Correlation of distance with various soil parameters (a)Soil Moisture (b) Soil Organic Carbon (c) Soil Organic matter (d) Soil pH (e) Soil Electrical Conductivity (f) Soil Salinity (g) Distance from the sacred groves $(\mathrm{km})(\mathrm{h})$ Land area of the farmland (hectares) $(\mathrm{N}=218)$

\begin{tabular}{lllllllll}
\hline & $\mathrm{a}$ & $\mathrm{b}$ & $\mathrm{c}$ & $\mathrm{d}$ & $\mathrm{e}$ & $\mathrm{f}$ & $\mathrm{g}$ & $\mathrm{h}$ \\
\hline $\mathrm{a}$ & 1.00 & & & & & & & \\
$\mathrm{~b}$ & 0.32 & 1.00 & & & & & & \\
$\mathrm{c}$ & 0.32 & 0.99 & 1.00 & & & & & \\
$\mathrm{~d}$ & -0.07 & 0.38 & 0.38 & 1.00 & & & & \\
$\mathrm{e}$ & -0.01 & -0.56 & -0.56 & -0.96 & 1.00 & & & \\
$\mathrm{f}$ & -0.80 & -0.57 & -0.57 & -0.41 & 0.51 & 1.00 & & \\
$\mathrm{~g}$ & -0.54 & -0.58 & -0.58 & -0.74 & 0.80 & 0.85 & 1.00 & \\
& -0.07 & -0.09 & 0.09 & -0.06 & 0.03 & 0.02 & 0.05 & 1.00 \\
\hline
\end{tabular}

As evident from table 4, soil parameters such as soil moisture, organic carbon organic matter and $\mathrm{pH}$ show a negative correlation with distance $(\mathrm{r}=-0.54,-0.58,-0.58,-$ 0.74 respectively) which implies that the farther we move from the sacred groves the soil parameters get declined which further leads to disrupted soil nutrient cycling. The other soil parameters like EC and Salinity are positively correlated with both distances from the sacred groves and the Land area of the farmland which indicates intervention of manual inputs in terms of fertilizers and manures by the farmers.

The causal relationship between the distance of sacred groves from the farmland, the area of the farmland, and the soil parameters have been estimated using multiple regression analysis to infer how the soil parameters impacted on increasing the distance from the sacred groves. The regressions were done with all the soil parameters mentioned in table 5 . It has been observed that an increase in distance by $1 \mathrm{~km}$ leads to a decrease in soil moisture, organic carbon, organic matter, and $\mathrm{pH}$ by $4 \%, 2 \%, 7 \%$, and $2 \%$ respectively. This implies that the farther we move from the sacred groves the soil parameters tend to decline and become less fertile to sustain natural vegetation as well as cultivation. This supports our argument to conserve these small yet imperative patches of forest surviving despite the arid topography.
Table-5: Regression Results $\left(\mathrm{N}=218 ;{ }^{*} \mathrm{P}<0.01\right)$

\begin{tabular}{|c|c|c|}
\hline \multirow{2}{*}{$\frac{\text { Variables }}{\text { Soil moisture }}$} & \multicolumn{2}{|c|}{ Coefficient (Std Error) } \\
\hline & & \\
\hline Distance from the sacred groves $(\mathrm{km})$ & $-0.04^{*}$ & $(0.003)$ \\
\hline Land area of the farmland (hectare) & $-0.002^{*}$ & $(0.003)$ \\
\hline Constant & 1.17 & $(0.05)$ \\
\hline \multicolumn{3}{|l|}{ Soil Organic Carbon } \\
\hline Distance from the sacred groves $(\mathrm{km})$ & $-0.02^{*}$ & $(0.001)$ \\
\hline Land area of the farmland (hectare) & 0.004 & $(0.001)$ \\
\hline Constant & 0.4 & $(0.03)$ \\
\hline \multicolumn{3}{|l|}{ Soil Organic Matter } \\
\hline Distance from the sacred groves $(\mathrm{km})$ & $-0.07^{*}$ & $(0.006)$ \\
\hline Land area of the farmland (hectare) & 0.01 & $(0.006)$ \\
\hline Constant & 1.5 & (o.09) \\
\hline \multicolumn{3}{|l|}{ Soil pH } \\
\hline Distance from the sacred groves $(\mathrm{km})$ & $-0.2^{*}$ & $(0.01)$ \\
\hline Land area of the farmland (hectare) & $-0.008^{*}$ & $(0.01)$ \\
\hline Constant & 6.7 & $(0.21)$ \\
\hline \multicolumn{3}{|l|}{ Soil Salinity } \\
\hline Distance from the sacred groves $(\mathrm{km})$ & 0.08 & $(0.003)$ \\
\hline Land area of the farmland (hectare) & $-0.002^{*}$ & $(0.003)$ \\
\hline Constant & 1.03 & $(0.04)$ \\
\hline \multicolumn{3}{|l|}{ Soil Electrical Conductivity } \\
\hline Distance from the sacred groves $(\mathrm{km})$ & $92.03^{*}$ & $(4.6)$ \\
\hline Land area of the farmland (hectare) & -0.5 & $(4.1)$ \\
\hline Constant & -201.9 & $(66.7)$ \\
\hline
\end{tabular}

Following are the description of the documented villages in the propinquity to the selected sacred groves along with their diagnostic characteristics:

Sadhay Pir Sacred grove (SP): it covers 3 hectares of an area inside Gugaliyana reserve forest and is located in $23^{\circ} 33^{\prime} 43.35^{\prime \prime} \mathrm{N}, 68^{\circ} 59^{\prime} 37.12^{\prime \prime}$ E direction. Known for its ageold trees and water spring this sacred grove is worshipped. Soil moisture is highest among all the surveyed villages and sacred groves but due to overgrazing by cattle; Sadhaypir needs more attention so that the land can become fit for natural vegetation. Land becomes less conducive to vegetation. It only has the invasive species Prosopis juliflora rampant in its vicinity.

Valka Nana village (VN): $3.52 \mathrm{~km}$ from SadhayPir sacred grove, 233' $50.98^{\prime \prime} \mathrm{N}, 69^{\circ} 01^{\prime} 50.46^{\prime \prime} \mathrm{E}$, and the community cultivating castor and cotton in their farmland. The physicochemical results of the soil from the farmland of the village show that the soil moisture, organic content, and salinity are at par with the cultivation of crops. Soil moisture being naturally sustained parameter shows naturally high value due to the proximity to the sacred groves whereas other parameters are influenced by the use of manures and fertilizers by farmers in their farmlands.

ValkaMota village (VM): Though located at $3.36 \mathrm{~km}$ from SadhayPir sacred grove, this village is located $23^{\circ} 35^{\prime} 15.26^{\prime \prime} \mathrm{N}$, $68^{\circ} 59^{\prime} 41.34^{\prime \prime} \mathrm{E}$ in direction and very dry and less productive due to overgrazing by cattle which is monitored by the villagers. There is low land productivity which is quite 
evident in terms of having very low organic content despite having sufficient soil moisture (Tables-2,3). The major reason behind this condition is low agricultural practices in the village due to the migration of village dwellers to the city for better job opportunities, unlike Valka nana village.

Dayapar Village (DP): the village is located $23^{\circ} 3^{\prime}$ '04.29" N, 68 $54^{\circ}$ '06.75” E. $13.45 \mathrm{~km}$ from Oran Mata sacred grove and $13.60 \mathrm{~km}$ from Sadhaypir sacred grove this village is cultivating groundnut and castor in its farmland. The acidity of the soil is so high that it can only cater to plants that can withstand desert conditions. The other parameters of the soil fail to allow the cultivation of vegetables and guggal.

Ghadani village (Gh): the village is located $23^{\circ} 3^{2} 27.13^{\prime \prime} \mathrm{N}$, $69^{\circ} 02^{\prime} 15.84$ " E. $6.16 \mathrm{~km}$ from Oran Mata sacred grove and $6.12 \mathrm{~km}$ from SadhayPir sacred grove this village plants cotton and groundnut though it faces interference of naturally rampant Prosopis. The soil moisture is very less, soil acidic and non-conducive to agricultural practices hence farmers use fertilizers and pesticides in their farmlands to influence the productivity of the land and also to get better security of the crops. The influence of manual inputs in terms of fertilizers and manures has resulted in an unanticipated hike in the organic content of the soil.

Mata Na Madh village (MNM): $2.86 \mathrm{~km}$ from Oran Mata sacred grove and $2.70 \mathrm{~km}$ from SadhayPir, (2332'39.63" N, $68^{\circ} 57^{\prime} 01.73^{\prime \prime}$ E). Plants like Bajra, pomegranate, groundnut, castor, cotton, and pulses are cultivated in the village. Farmers of the village apply fertilizers and pesticides in their farmland to protect their crops from pests and the infestation of rats. Soil moisture shows high content making the soil efficient for the cultivation of plants. Also, the impact of such an application in the farmland has promoted changes in the soil's organic content.

Lifri village (LV): $3.69 \mathrm{~km}$ from Oran Mata sacred grove and $3.90 \mathrm{~km}$ from Sadhaypir sacred grove with the location $23^{\circ} 30^{\prime} 19.35^{\prime \prime} \mathrm{N}, 68^{\circ} 5^{\prime} 59.77^{\prime \prime} \mathrm{E}$, this village is inhabited by Sodha community which is considered as refugees by village patwari and department of the forest. There are only 43 total households, no agricultural activity is happening in this village and villagers get all the resources from either nearby villages or city. The available land is dedicated to pasturing and this is the major reason for low soil organic content despite being close to both the sacred groves.

Oran Mata Sacred grove (OM): located in 23032'31.66” N, 68 59 '12.69" E. Covering an area of 2 hectares Oran Mata sacred grove forms a part of Gugaliyana Reserve Forest (2229.26 hectares). Few juvenile species of Guggal (Commiphora whightii) are currently available inside the grove premises which take 20 years to mature. The presence of old water wells has made the soil conducive to catering to vegetation with high soil moisture and organic content and low salinity. Guggal is not only utilized in yajna but also has been medicinally used in the cure of high blood pressure and heart-related problems. Lignite mining site adjacent to the grove (GMDC) is also a major reason behind such a condition today.

Paneli Village (PV): $7.33 \mathrm{~km}$ from Oran Mata and $7.20 \mathrm{~km}$

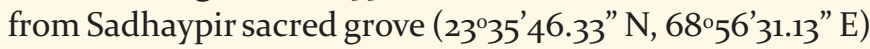
have agricultural crop pattern same as other villages but soil quality is influenced using fertilizers and pesticides. Also, it has been observed while testing the soil that with a distance of more than $5 \mathrm{~km}$ from Gugaliyana reserve forest there is a decline in the natural health of the soil and so manure and fertilizers have been used.

Dolatpar Village (DOP): Located in $23^{\circ} 35^{\prime} 51.26^{\prime \prime} \mathrm{N}$, $68^{\circ} 5^{2} 26.65^{\prime \prime}$ E with a distance of $10.95 \mathrm{~km}$ from Oran Mata and $10.90 \mathrm{~km}$ from Sadhaypir sacred grove. This village is agriculturally more intensive than other villages as the farmers here are cultivating many crop species and also use more seeds, fertilizers, and manures for agriculture. Naturally, the soil is acidic and not fit for agricultural practices but with higher usage of chemical fertilizers, the cultivation of crops conducive to the arid region is done.

Soil organic carbon sequestration potential of selected sacred groves: Organic Carbon sequestered potential of the selected sacred groves has been assessed from the results of soil organic carbon of various village fields. The results were obtained at the soil depth of thickness $15 \mathrm{~cm}$ and the bulk density of $1.89 \mathrm{~g} / \mathrm{cm}_{3}$, soil organic carbon sequestered for Oran Mata sacred grove is $11.7 \mathrm{t} / \mathrm{ha} /$ depth whereas for Sadhay Pir sacred grove it is $3.78 \mathrm{t} / \mathrm{ha} / \mathrm{depth}$. The soil organic carbon sequestered is relatively higher at Oran Mata, as compared to the soil organic carbon measured at SadhayPir. This can be because of the ecological succession which gives rise to phase-wise natural deposition of sediments and biodegradable attributes in the layers of soil over the years. This phenomenon contributes to the natural carbon cycle and other sedimentary cycles in the ecosystem. This finding is in congruence with the findings of Tanwar et al. (2019) about the carbon sequestration in arid zones of Indian origin. This adds to the benefits of preserving SG in a desert ecosystem. The contribution of carbon sequestration potential in the unique desert ecosystem could be studied further in later research.

In desert context soil moisture greater than $1 \%$ makes a considerable difference to the crops that may be cultivated. This is because in extremely arid conditions it is difficult to maintain the soil moisture content of even $2 \%$. It has been observed that proximity to the sacred grove is of major importance in protecting the soil parameters. Soil moisture has a moderate negative correlation with the proximity of the sacred grove which implies that the farther we move from the sacred grove, the more the decline in soil moisture. The other soil parameters are seen to be weakly correlated (correlation of soil parameters with distance from the sacred groves is presented in Table-4). Soil 
moisture is one such parameter that rarely gets affected by fertilizers and manures unlike other parameters (Gwak \& Kim 2017). Soil parameters like $\mathrm{pH}$, organic content are influenced by the addition of fertilizers and manures (Gelman et al., 2011) which has also been observed in our study. The soil quality declined for villages that are not influenced by the sacred groves, the organic content is very low, and it cannot sustain medicinal plants, pulses, and vegetables unlike the villages close to the sacred groves. The villages (Dolatpar, Dayapar, and Paneli) also have higher soil salinity and groundwater salinity. This study highlights the need to protect sacred grove in such severe droughtprone areas which have no alternative resources for livelihood.

Conclusively, in an arid zone of Kachchh, the impact of climate change will be severe $(345 \mathrm{~mm}$ rain which is very much below the average annual rainfall for India) and huge anthropogenic pressures in terms of overgrazing of the livestock, developmental activities in terms of lignite mining nearby the sacred groves and construction on the fringes of the groves are reducing the productivity of the land and causing threat to the natural vegetation and resources. As per the forest department of west division Kachchh there is an immediate need to limit the number of cattle entering the fringes of the reserve forest so that the grazing activity shouldn't encroach the area of the sacred grove. It has been observed that the younger generation in the villages is not connected to the sacred groves, there is a need for educational training and field expeditions at the academic level for the students and upcoming generations to be acclimatized with the concept and practice of sacred groves and they should be encouraged to actively participate in the conservational assignments from neighbouring towns and cities. Sensitization of the local people on regular basis regarding the sustainable utilization of natural resources and methods which should be incorporated in their agricultural practices to help them increase the yield of the farmland and overall productivity of the land.

\section{Acknowledgement:}

The authors of the present paper would like to place on record the constant support and encouragement received from Prof. Saudamini Das, IEG, New Delhi and Dr. Kavita Sardana, TERISAS, New Delhi. We also would like to thank the director GUIDE,
Bhuj, Gujarat for his constant support and encouragement during the course of study. The authors would like to duly acknowledge the financial support provided by Indian Council of Social Science Research (ICSSR), New Delhi, India in association with the Institute of Economic Growth, New Delhi, through its doctoral fellowship. It is imperative to mention the guidance and support received from Dr. Arun Kumar Roy Mahato and Dr. Rachna Chandra from GUIDE, Bhuj. Also, heartfelt gratitude to all the villagers and priests who have been the pillar of the study and have given immense support and time to make the research possible.

\section{References:}

Gadgil, M. \& Vartak, V.D. (1976): The sacred groves of Western Ghats in India. Econ. Bot., 30(2):152-160.

Gelman, F., Binstock, R. \& Halicz, L. (2011): Application of the Walkley-Black Titration for Organic Carbon Quantification on Organic-rich Sedimentary Rocks. Pub. by: Ministry of National Infrastructures-Geological survey of Israel.

Gwak, Y. \& Kim, S. (2017): Factors affecting soil moisture spatial variability for a humid forest hillslope. Hydrol. Process., 31(2):431-445.

Måren, I.E., Karki, S., Prajapati, C., Yadav, R.K. \& Shrestha, B.B. (2015): Facing north or south: does slope aspect impact forest stand characteristics and soil properties in a semiarid transHimalayan valley? J. Arid Environ., 121:112-123.

Pandey, A. \& Mahato, A. (2019): Restoration potential of degraded inland sacred forest of Kachchh, Gujarat: an evidence of Shravan Kavadiya Sacred grove. Int. J. Pharma Biosci., 10(3):171-180

Pandey, A. \& Mahato, A. (2019): The forest of reverence (Sacred Groves) in the Arid biogeographic province of India: a literature-based comparison with the Sacred Groves of the Arid deserts of the world. Ambient Sci., 06(1):05-10.

Pandey, D.N. (1999): Sacred forestry: the case of Rajasthan, India. Sustain. Develop. Int., 1-6.

Patel, R.M., Mahato, A.K.R. \& Yatin, S.P., 2014. Study on the floristic diversity of two newly recorded sacred groves from Kachchh district of Gujarat, India. L. Plant Sci., 3(1):75-81.

Swamy, P.S., Kumar, M. \& Sundarapandian, S.M. (2003): Spirituality and ecology of sacred groves in Tamil Nadu, India. UNASYLVA-FAO:53-55.

Tanwar, S.P.S., Kumar, P., Verma, A., Bhatt, R.K., Singh, A., Lal, K., Patidar, M. \& Mathur, B.K. (2019): Carbon sequestration potential of agroforestry systems in the Indian arid zone. Current Sci., 117(12):2014.

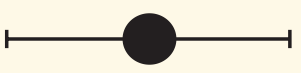

